\title{
Importance of intertidal sediment processes and porewater exchange on the water column biogeochemistry in a pristine mangrove creek (Ras Dege, Tanzania)
}

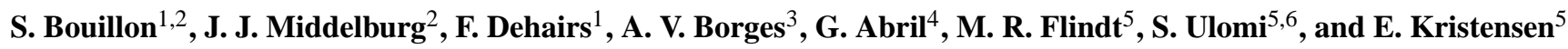 \\ ${ }^{1}$ Vrije Universiteit Brussel, Dept. of Analytical and Environmental Chemistry, Pleinlaan 2, 1050 Brussels, Belgium \\ ${ }^{2}$ Netherlands Institute of Ecology, Centre for Estuarine and Marine Ecology (NIOO-KNAW), Yerseke, The Netherlands \\ ${ }^{3}$ Université de Liège, Chemical Oceanography Unit, Institut de Physique (B5), 4000 Liège, Belgium \\ ${ }^{4}$ Environnements et Paléoenvironnements Océaniques (EPOC), CNRS-UMR 5805, Université Bordeaux 1, Avenue des \\ Facultés, 33405, Talence, France \\ ${ }^{5}$ Institute of Biology, University of Southern Denmark, 5230 Odense, Denmark \\ ${ }^{6}$ Faculty of Aquatic Sciences and Technology, University of Dar es Salaam, Tanzania
}

Received: 15 January 2007 - Published in Biogeosciences Discuss.: 31 January 2007

Revised: 4 April 2007 - Accepted: 30 May 2007 - Published: 12 June 2007

\begin{abstract}
We sampled a tidal creek (Ras Dege, Tanzania) during a 24-h cycle to document the variations in a suite of creek water column characteristics and to determine the relative influence of tidal and biological driving forces. Since the creek has no upstream freshwater inputs, highest salinity was observed at low tide, due to evaporation effects and porewater seepage. Total suspended matter (TSM) and particulate organic carbon (POC) showed distinct maxima at periods of highest water flow, indicating that erosion of surface sediments and/or resuspension of bottom sediments were an important source of particulate material. Dissolved organic carbon (DOC), in contrast, varied in phase with water height and was highest at low tide. Stable isotope data of POC and DOC displayed large variations in both pools, and similarly followed the variations in water height. Although the variation of $\delta^{13} \mathrm{C}_{\mathrm{DOC}}(-23.8$ to $-13.8 \%$ o) was higher than that of $\delta^{13} \mathrm{C}_{\mathrm{POC}}(-26.2$ to $-20.5 \%$ ), due to the different endmember pool sizes, the $\delta^{13} \mathrm{C}$ signatures of both pools differed only slightly at low tide, but up to $9 \%$ at high tide. Thus, at low tide both DOC and POC originated from mangrove production. At high tide, however, the DOC pool had signatures consistent with a high contribution of seagrass-derived material, whereas the POC pool was dominated by marine phytoplankton. Daily variations in $\mathrm{CH}_{4}$, and partial pressure of $\mathrm{CO}_{2}\left(\mathrm{pCO}_{2}\right)$ were similarly governed by tidal influence and were up to 7- and 10-fold higher at low tide, which stresses the importance of exchange of porewater and diffusive fluxes to the water column. When assuming that the high dissolved
\end{abstract}

Correspondence to: S. Bouillon

(steven.bouillon@vub.ac.be) inorganic carbon (DIC) levels in the upper parts of the creek (i.e. at low tide) are due to inputs from mineralization, $\delta^{13} \mathrm{C}$ data on DIC indicate that the organic matter source for mineralization had a signature of $-22.4 \%$. Hence, imported POC and DOC from the marine environment contributes strongly to overall mineralization within the mangrove system. Our data demonstrate how biogeochemical processes in the intertidal zone appear to be prominent drivers of element concentrations and isotope signatures in the water column, and how pathways of dissolved and particulate matter transport are fundamentally different.

\section{Introduction}

Vegetated coastal ecosystems are critical components of global ocean carbon and nutrient budgets. Despite their relatively small areal extent, their carbon sequestration represents a large inventory of organic matter; comparable to global riverine carbon discharges (e.g. see Ludwig et al., 1996; Gattuso et al., 1998). In addition to their carbon burial capacity (Duarte et al., 2005), these ecosystems are also "hotspots" (McClain et al., 2003) in terms of mineralization (Middelburg et al., 2005) and $\mathrm{CO}_{2}$ efflux to the atmosphere (e.g., Cai et al., 1999; Borges, 2005). Understanding the functioning of these diverse ecosystems and constraining their carbon and nutrient budgets is therefore of prime importance in improving the reliability of global oceanic budgets. The surface area of mangrove ecosystems worldwide declines by $\sim 2 \%$ per year, implying major changes in the coastal carbon cycle (Duarte et al., 2005).

Published by Copernicus Publications on behalf of the European Geosciences Union. 


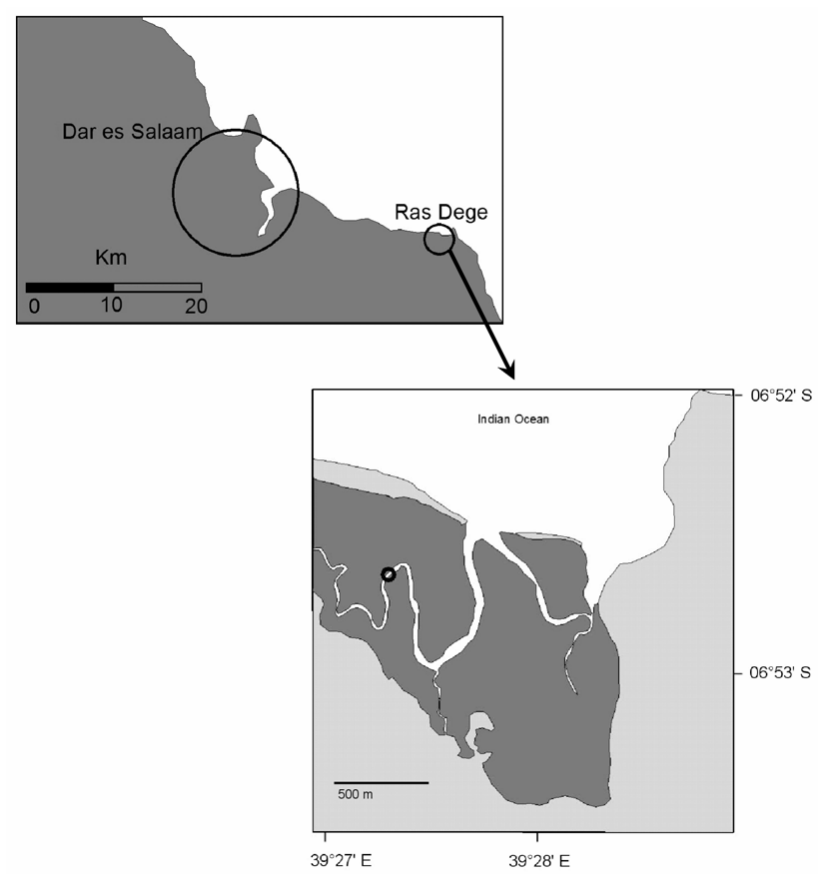

Fig. 1. Location of the study area and the sampling site, indicated by the circle in the lower panel. Dark areas in the lower panel indicate the areal cover of mangrove vegetation.

Mangrove ecosystems are limited to tropical and subtropical coastlines, but are known to be potentially significant sources of organic matter to adjacent estuaries and coastal waters on a global scale (Jennerjahn and Ittekkot, 2002; Dittmar et al., 2006). The biogeochemical functioning of mangrove environments has been well described for a number of sites around the world, but our ability to elucidate carbon and nutrient budgets of these ecosystems and their impact on the coastal zone is still limited. The transport of material between the intertidal zone and the water column (estuary, lagoon, or tidal creeks) is a crucial aspect in understanding the functioning of these systems (Flindt et al., 2004, 2007). Previous work has demonstrated that particulate organic matter can be exported from mangrove systems, but additionally, suspended matter from the water column can be an important source of organic matter to the intertidal zone (e.g., Hemminga et al., 1994; Bouillon et al., 2003, 2007a). Exchange of dissolved organic matter and nutrients between intertidal areas and the water column can occur through (i) diffusive fluxes across the sediment/water interface during inundation, or (ii) porewater seepage into the water column during low and ebb tide. Fluxes across the sediment/water interface have been frequently studied, but typically show a large variability in magnitude and direction of the fluxes for dissolved organic carbon (DOC) and inorganic $\mathrm{N}\left(\mathrm{NH}_{4}^{+}\right.$and $\mathrm{NO}_{3}^{-}$) (e.g. Kristensen et al., 2000; Davis et al., 2001). The potential exchange of dissolved solutes through advective porewater seepage has been proposed pre- viously for certain mangrove systems (Ovalle et al., 1990; Dittmar and Lara, 2001; Borges et al., 2003; Barnes et al., 2006), but was found to be insignificant in others (Kristensen and Suraswadi, 2002). Such exchange mechanisms have also been proposed for salt marsh systems (Cai et al., 1999), intertidal sand flats (Billerbeck et al., 2006a, b), and tidal freshwater marshes (Neubauer and Anderson, 2003; Gribsholt et al., 2005). The high metabolic activity in mangrove sediments creates elevated porewater concentrations of total alkalinity (TA), dissolved inorganic carbon (DIC), DOC, and other metabolites (e.g., Marchand et al., 2006; Bouillon et al., 2007b). During ebb, porewaters can migrate into the water column and increase the concentrations of these solutes (Ovalle et al., 1990; Borges et al., 2003; Barnes et al., 2006). Porewater discharge into tidal creeks may also lower dissolved oxygen levels. The rate of porewater migration depends on the sediment permeability and the pressure gradient. Crab burrows have been found to dramatically enhance the hydraulic conductivity, and given their abundance in mangrove systems, these could be important mediators for subsurface flow of porewater to tidal creeks (Ridd, 1996; Susilo and Ridd, 2005; Mazda and Ikeda, 2006).

Recognizing and understanding the pathways of exchange between the intertidal zone and the adjacent water column is important for improving carbon budgets - this holds true not only for mangroves but also for other tidal systems such as salt marshes and tidal freshwater marshes. Mineralization rates measured in intertidal sediments (as $\mathrm{CO}_{2}$ effluxes), for example, are likely to underestimate true mineralization rates if a significant part of the $\mathrm{CO}_{2}$ (or DIC) generated is mobilized into the water column through seepage. Conversely, estimates of water-air $\mathrm{CO}_{2}$ exchange in tidal creeks will overestimate creek water respiration if there is significant lateral input from porewater drainage. Lateral exchange of dissolved organic matter due to subsurface drainage from sediments and transfer to creeks represents a clear case of external subsidy for tidal creek organisms.

In order to shed more light on the pathways of organic matter transport between the intertidal mangrove forest and the aquatic system, we investigated the tidal variations in water column biogeochemical signatures in a mangrove creek along the Tanzanian coast, with a focus on the concentrations and origin of POC, DOC, and DIC.

\section{Materials and methods}

Samples were collected on 16 and 17 September 2005 at hourly intervals during a diurnal cycle in the Ras Dege mangrove forest, which is situated approximately $30 \mathrm{~km}$ southeast of Dar es Salaam, Tanzania (Fig. 1). The sampling station $\left(6^{\circ} 52^{\prime} 30^{\prime \prime} \mathrm{S}, 39^{\circ} 27^{\prime} 30^{\prime \prime} \mathrm{E}\right)$ is located in a tidal creek, approximately midway between its upper reaches and its opening towards the Indian Ocean (see Fig. 1). The site is located in a rural setting and has no major influences from 
anthropogenic wastewater inputs; therefore it can be considered a pristine site when compared to other mangrove sites around Dar es Salaam (e.g., see Kruitwagen et al., 2005). The sampling period fell towards the end of the dry season, and no precipitation occurred during the sampling period and the preceeding days. The mangrove forest in Ras Dege covers an area of $2.2 \mathrm{~km}^{2}$, and is dominated by Avicennia marina, Rhizophora mucronata, Sonneratia alba and Ceriops tagal. The system comprises 2 tidal creeks which open into the Indian Ocean, and which receive no freshwater inputs except during the rainy season. The system experiences semi-diurnal tides, with an amplitude ranging between $\sim 1$ m during neap tides to $\sim 4 \mathrm{~m}$ during spring tides. Tidal amplitude during the sampling period in the creek was approximately $2.6 \mathrm{~m}$ (Fig. 2). The water residence time is in the order of 2-3 days during the dry season (M. R. Flindt, unpublished data). The mouth of the creeks and the zone adjacent to the mouth are covered by seagrass beds.

Surface water for field measurements of dissolved $\mathrm{O}_{2}, \mathrm{pH}$, temperature and salinity was taken with a $1.7 \mathrm{~L}$ Niskin bottle $\sim 0.5 \mathrm{~m}$ below the surface. Oxygen saturation levels $\left(\% \mathrm{O}_{2}\right)$ were measured immediately after collection with a polarographic electrode (WTW Oxi-340) calibrated on saturated air, with an accuracy of $\pm 1 \%$. $\mathrm{pH}$ was measured using a Ross type combination electrode (ORION) calibrated on the NBS (US National Bureau of Standards) scale, as described by Frankignoulle and Borges (2001), with a reproducibility of $\pm 0.005 \mathrm{pH}$ units. Samples for determination of TA were obtained by pre-filtering $100 \mathrm{~mL}$ of water through precombusted Whatman GF/F filters followed by filtration through $0.2 \mu \mathrm{m}$ cellulose acetate syringe filters (Sartorius), and were stored in HDPE bottles until analysis by automated electro-titration on $50 \mathrm{~mL}$ samples with $0.1 \mathrm{M} \mathrm{HCl}$ as titrant (reproducibility better than $\pm 4 \mu \mathrm{mol} \mathrm{kg}{ }^{-1}$ ). The $\mathrm{pCO}_{2}$ and DIC concentrations were computed from $\mathrm{pH}$ and TA measurements using the thermodynamic constants described in Frankignoulle and Borges (2001), with an accuracy of computed DIC and $\mathrm{pCO}_{2}$ values estimated at $\pm 5 \mu \mathrm{mol} \mathrm{kg}{ }^{-1}$ and better than $\pm 2 \%$, respectively.

Water samples for the analysis of $\delta^{13} \mathrm{C}_{\mathrm{DIC}}$ were taken from the same Niskin bottle by gently overfilling $12 \mathrm{~mL}$ glass headspace vials, and poisoned with $20 \mu \mathrm{L}$ of a saturated $\mathrm{HgCl}_{2}$ solution. For the analysis of $\delta^{13} \mathrm{C}_{\mathrm{DIC}}$, a $\mathrm{He}$ headspace was created, and $\sim 300 \mu \mathrm{L}$ of $\mathrm{H}_{3} \mathrm{PO}_{4}$ was added to convert all inorganic carbon species to $\mathrm{CO}_{2}$. After overnight equilibration, part of the headspace was injected into the He stream of an EA-IRMS (Elemental Analyzer - Isotope Ratio Mass Spectrometer; ThermoFinnigan Flash1112 and ThermoFinnigan Delta+XL) for $\delta^{13} \mathrm{C}$ measurements. The obtained $\delta^{13} \mathrm{C}$ data were corrected for the isotopic equilibration between gaseous and dissolved $\mathrm{CO}_{2}$ using the algorithm presented in Miyajima et al. (1995). Water samples for the determination of $\mathrm{CH}_{4}$ concentrations were taken directly from the Niskin bottle in $40 \mathrm{~mL}$ headspace vials, poisoned with $\mathrm{HgCl}_{2}$, and capped with a butyl rubber plug and alu-

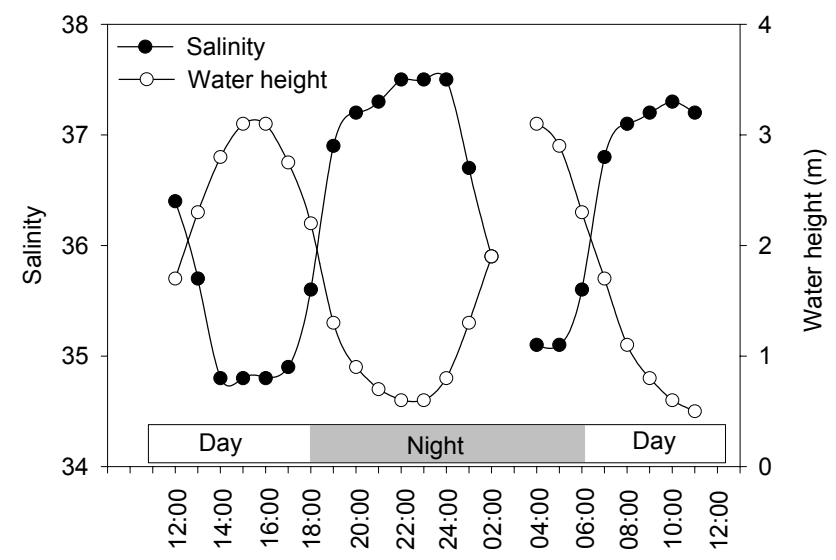

Fig. 2. Tidal variations of salinity in surface waters and water height.

minium cap. $\mathrm{CH}_{4}$ concentrations were determined by gas chromatography with flame ionization detection, after creating a headspace with $\mathrm{N}_{2}$, as described in Abril and Iversen (2002). Certified $\mathrm{CH}_{4}: \mathrm{N}_{2}$ mixtures at 10 and 500 ppmv $\mathrm{CH}_{4}$ were used as standards (Air Liquide, France). Dissolved $\mathrm{CH}_{4}$ concentration was calculated with the solubility coefficient of Yamamoto et al. (1976). Reproducibility was generally better than $5 \%$.

Samples for TSM were filtered immediately on preweighed and pre-combusted (overnight at $450^{\circ} \mathrm{C}$ ) $47 \mathrm{~mm}$ Whatman GF/F filters, rinsed with mineral water to avoid salt contributions, and subsequently dried. Samples for POC, particulate nitrogen (PN), and $\delta^{13} \mathrm{C}_{\mathrm{POC}}$ were filtered on precombusted $25 \mathrm{~mm}$ Whatman GF/F filters and dried. These filters were later decarbonated with $\mathrm{HCl}$ fumes under partial vacuum for $4 \mathrm{~h}$, re-dried and packed in Ag cups. POC and PN were determined on a ThermoFinnigan Flash EA1112 using acetanilide as a standard, and the resulting $\mathrm{CO}_{2}$ was measured on a ThermoFinnigan delta $+\mathrm{XL}$ interfaced via a Conflo III to the EA. Reproducibility of $\delta^{13} \mathrm{C}_{\mathrm{POC}}$ measurements was better than $\pm 0.2 \%$. Samples for DOC and $\delta^{13} \mathrm{C}_{\mathrm{DOC}}$ were obtained by pre-filtering surface water on pre-combusted Whatman GF/F filters, followed by filtration on $0.2 \mu \mathrm{m}$ cellulose acetate syringe filters (Sartorius), and preserved by addition of $50 \mu \mathrm{L}$ of $\mathrm{H}_{3} \mathrm{PO}_{4}$. DOC concentrations and $\delta^{13} \mathrm{C}$ signatures were measured with a modified Thermo HiperTOC TOC-analyzer, interfaced with a Thermo delta +XL IRMS as described by Bouillon et al. (2006).

Triplicate sediment cores $(5 \mathrm{~cm}$ i.d.) were taken within the mangrove forest at different sites along the creek for analysis of pore water DIC and DOC. The cores were sectioned into $0-1,1-2,2-3,3-4,4-6,6-8,10-12$, and $14-16 \mathrm{~cm}$ intervals. Pore water was extracted by transferring the sediment slices to $50 \mathrm{~mL}$ tubes followed by centrifugation at $5000 \mathrm{rpm}$ for $10 \mathrm{~min}$. The supernatant pore water was analyzed for DIC by the flow injection/diffusion cell technique (Hall and 

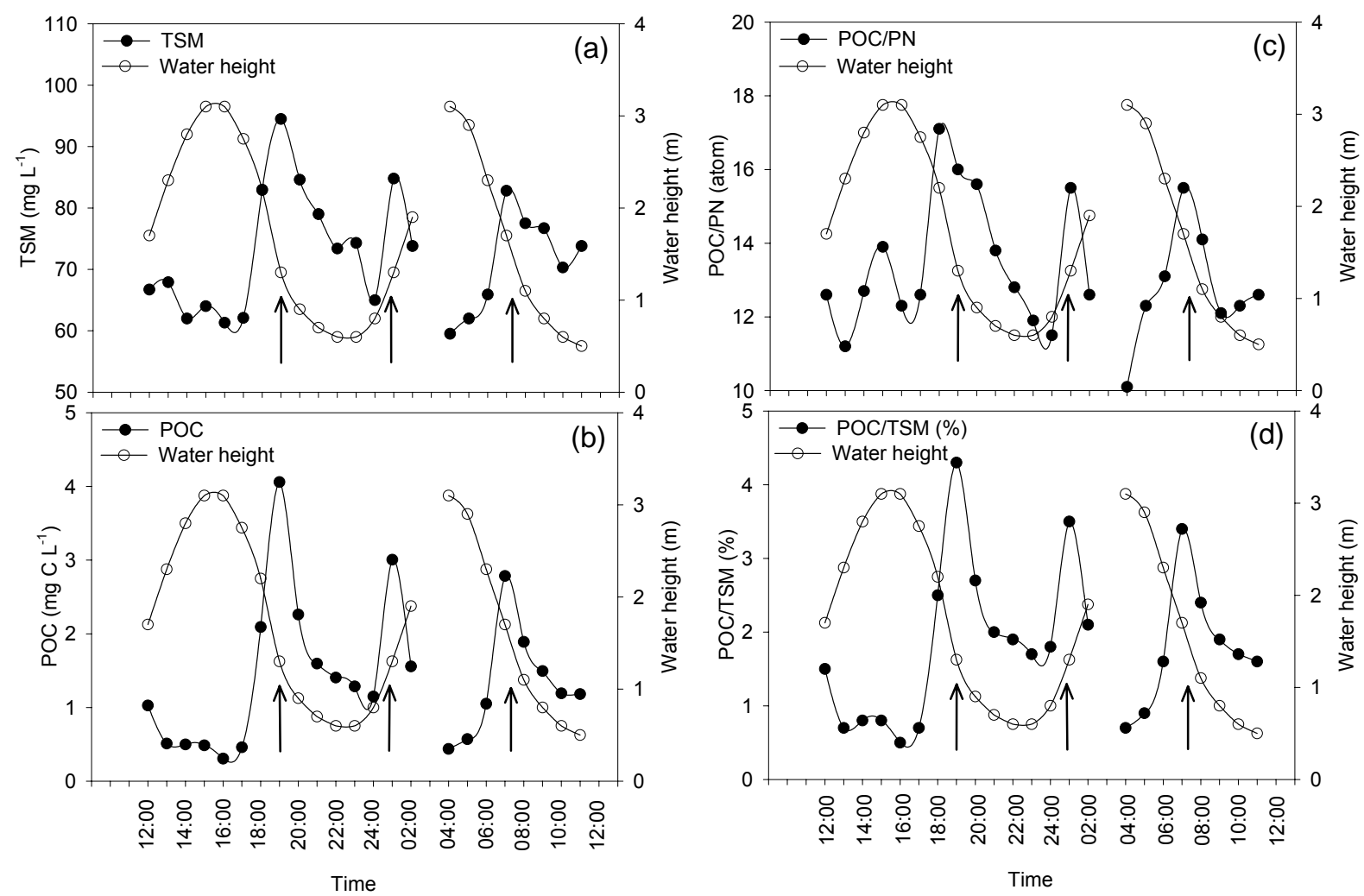

Fig. 3. Tidal variations of water height and (a) TSM, (b) POC, (c) POC/PN ratios (atom) of suspended matter, and (d) the \% contribution of POC to the TSM pool. Arrows indicate distinct maxima coinciding with highest tidal currents.

Aller, 1992) and DOC by total organic carbon analysis (Shimadzu TOC-5000; Kristensen and Alongi, 2006). Salinity was calculated from $\mathrm{Cl}^{-}$concentrations (measured by ion chromatography) according to the empirical relationship: salinity $=0.0641 *\left[\mathrm{Cl}^{-}\right]+0.0545$ where $\left[\mathrm{Cl}^{-}\right]$is expressed in $\mathrm{mM}$.

\section{Results}

Salinity values ranged from a high of almost 38 at low tide to less than 35 when oceanic water dominated at high tide (Fig. 2). Thus, the upper parts of the creek typically showed a higher salinity than the outer part connected to the Indian Ocean, due to the absence of freshwater inputs and evaporation.

TSM levels ranged between 60 and $95 \mathrm{mg} \mathrm{L}^{-1}$ and showed two distinct tidal maxima (i.e. maxima occurred on three occasions, twice during ebb and once during flood), coinciding with periods of strong water currents (Fig. 3a). POC ranged between 0.31 and $4.06 \mathrm{mg} \mathrm{C} \mathrm{L}^{-1}$ and displayed peak values at the same time as observed in TSM (Fig. 3b). These peaks also coincided with maxima in the POC/PN ratios and with maxima in the contribution of POC to the TSM pool (Figs. 3c, d). In contrast to POC, DOC showed variations that correlated strongly with salinity and mirrored those of the water column height, i.e. with lowest values at high tide and highest values at low tide (Fig. 4a). The stable isotope composition of both POC and DOC showed strong tidal variations, both having more depleted $\delta^{13} \mathrm{C}$ signatures at low tide and enriched $\delta^{13} \mathrm{C}$ values at high tide (Fig. 4b). However, variations in $\delta^{13} \mathrm{C}_{\mathrm{POC}}$ and $\delta^{13} \mathrm{C}_{\mathrm{DOC}}$ exhibited two important differences: (i) the fluctuations in $\delta^{13} \mathrm{C}_{\mathrm{DOC}}$ were delayed slightly relative to those of $\delta^{13} \mathrm{C}_{\mathrm{POC}}$, i.e. when the water level dropped, $\delta^{13} \mathrm{C}$ signatures of the DOC pool responded later than those of the POC pool, and (ii) the amplitude of variation observed in $\delta^{13} \mathrm{C}_{\mathrm{DOC}}$ was more pronounced, ranging between -23.8 and $-13.8 \%$, compared to a range between -26.2 and $-20.5 \%$ o for POC (Fig. 4b). These patterns, in combination with the different DOC and POC pool sizes at low and high tide, resulted in strong tidal difference in $\delta^{13} \mathrm{C}$ between both pools $(\Delta \delta)$, showing minimum values of $0.3-$ $2.5 \%$ at low tide and maximum values of $6.5-9.0 \%$ shortly after the peak of high tide (Fig. 4c).

Variations in $\mathrm{pCO}_{2}$ and $\mathrm{CH}_{4}$ concentrations were similar, being lowest at high tide and increasing drastically at low tide, reaching values 6- to 10-fold and 4- to 7-fold higher, respectively, than at high tide (Fig. 5a). The inorganic carbon pool showed similar dynamics as those in the DOC pool, i.e. highest TA and DIC at low tide (Fig. 5b). $\delta^{13} \mathrm{C}$ signatures 
in the DIC pool were close to typical oceanic values $(\sim 0 \%$ o) at high tide, and became strongly negative during low tide, reaching $\sim-9 \%$ (Fig. 5c).

Oxygen saturation levels followed the tidal cycle and ranged from 59\% at low tide to $111 \%$ at high tide (Fig. 5d). The level at high tide was dependent on light and exhibited higher values during daytime (100-110\%) than during night (80-90\%), likely due to oxygen production by primary producers during daytime.

\section{Discussion}

4.1 Salinity variations and importance of porewater seepage

The Ras Dege mangrove forest had characteristics of an "inverse estuary", i.e. a tidal system without freshwater inputs where the salinity values are elevated at low tide in the upper reaches of the creek. This is a regular feature in mangrove creeks, and is typically observed during prolonged dry periods with high evaporation rates (Wolanski, 1986; Kitheka, 1996). Salinity variations therefore presented a mirror image of the water column height (Fig. 2), with typical oceanic values at high tide $(\sim 35)$, but increasing to nearly 38 at low tide. Porewater salinities at the forest floor $(0-12 \mathrm{~cm})$ measured during the same field campaign along the sampled creek showed high salinity levels, with an average of $39.5 \pm 2.2(n=16)$ near the mouth of the creek and 47.4 \pm 4.7 $(n=18)$ near the head of the creek. The tidal variations in salinity suggest that porewater seepage is the main source of the elevated salinity at low tide (see also Ovalle et al., 1990; Dittmar and Lara, 2001). Under this assumption, and using the porewater and high tide salinity values as end members, our data indicate that the porewater contribution to the creek at our sampling station is approximately $30 \%$ during the low tide slack, when water levels drops well below the creek bank level (Fig. 2, Table 1). The exchange of solutes in mangrove environments is likely enhanced by burrow structures constructed by the resident fauna. Crab burrows, which are often very densely distributed, have been demonstrated to increase the hydraulic conductivity of mangrove sediments (Ridd, 1996; Susilo and Ridd, 2005; Susilo et al., 2005) and create a larger effective surface area where diffusive exchange of solutes between the sediment and water can take place. Their role in enhancing direct solute exchange can thus be considered as an ecosystem engineering impact, which adds to their documented importance for litter retention, foodweb interactions and habitat modification (e.g. see Lee, 1997, 1998).

\subsection{Origin and exchange of organic matter}

Export of particulate organic matter is considered an important feature of mangrove systems and has been suggested to represent both a major fate of the ecosystem production and

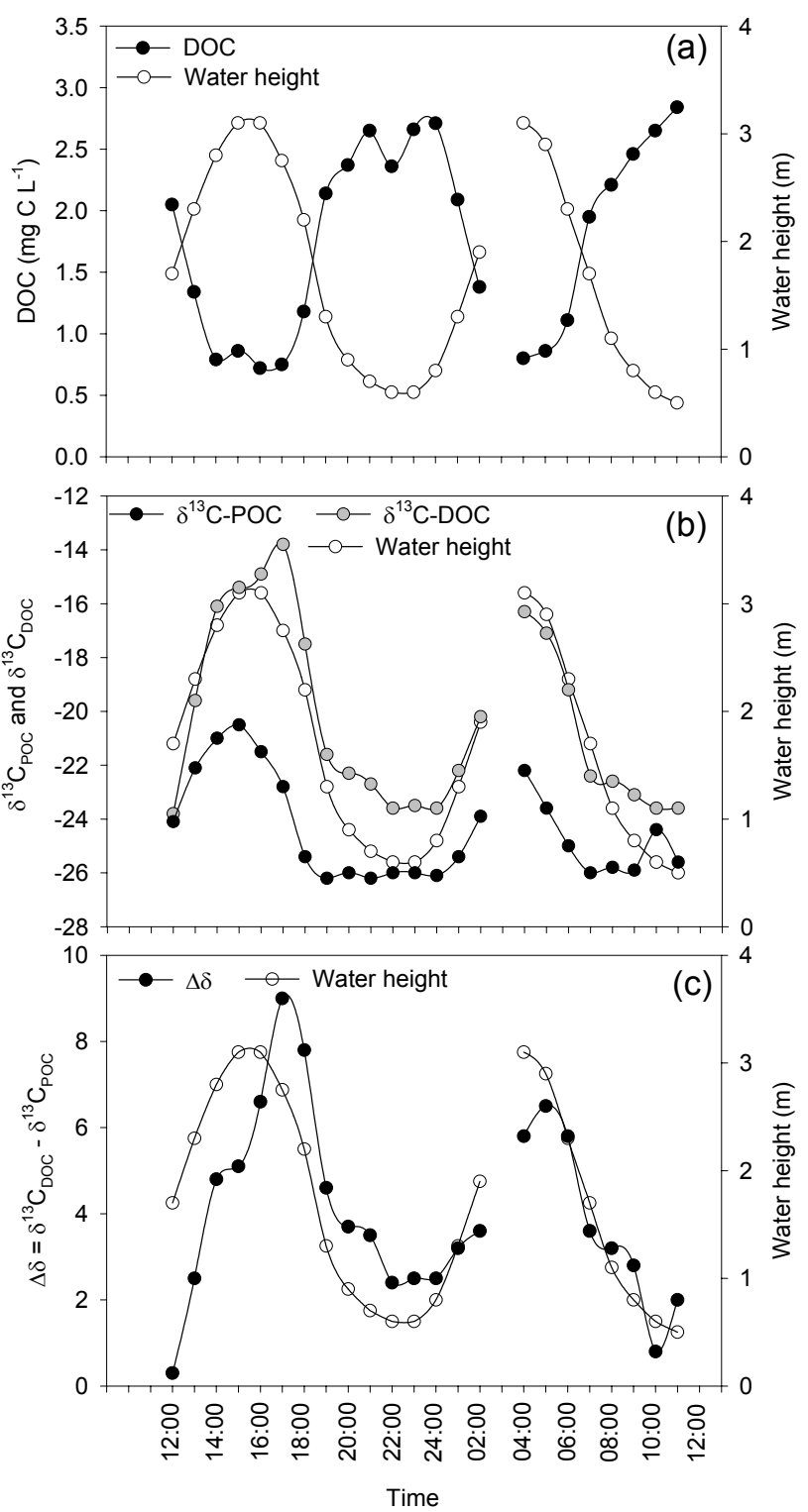

Fig. 4. Tidal variations of water height and (a) dissolved organic carbon concentrations, (b) carbon stable isotope signatures in particulate and dissolved organic carbon, and (c) the difference in $\delta^{13} \mathrm{C}$ between DOC and POC.

a significant source of organic matter to the adjacent marine environment (e.g. Lee, 1995; Jennerjahn and Ittekkot, 2002). Our tidal data indicated distinct peaks in the particulate matter pool and its composition when water current velocities are highest during each period of ebb and flood (Figs. 3a, b). Similar observations have been made in a degraded mangrove creek by Kitheka et al. (2002), who demonstrated that TSM and POC maxima occurred at periods of highest current velocities in the front waters of the creek, and by Boto and Bunt (1981) in a northern Australian mangrove creek. The rapid increase in POC we observed coincided with an 


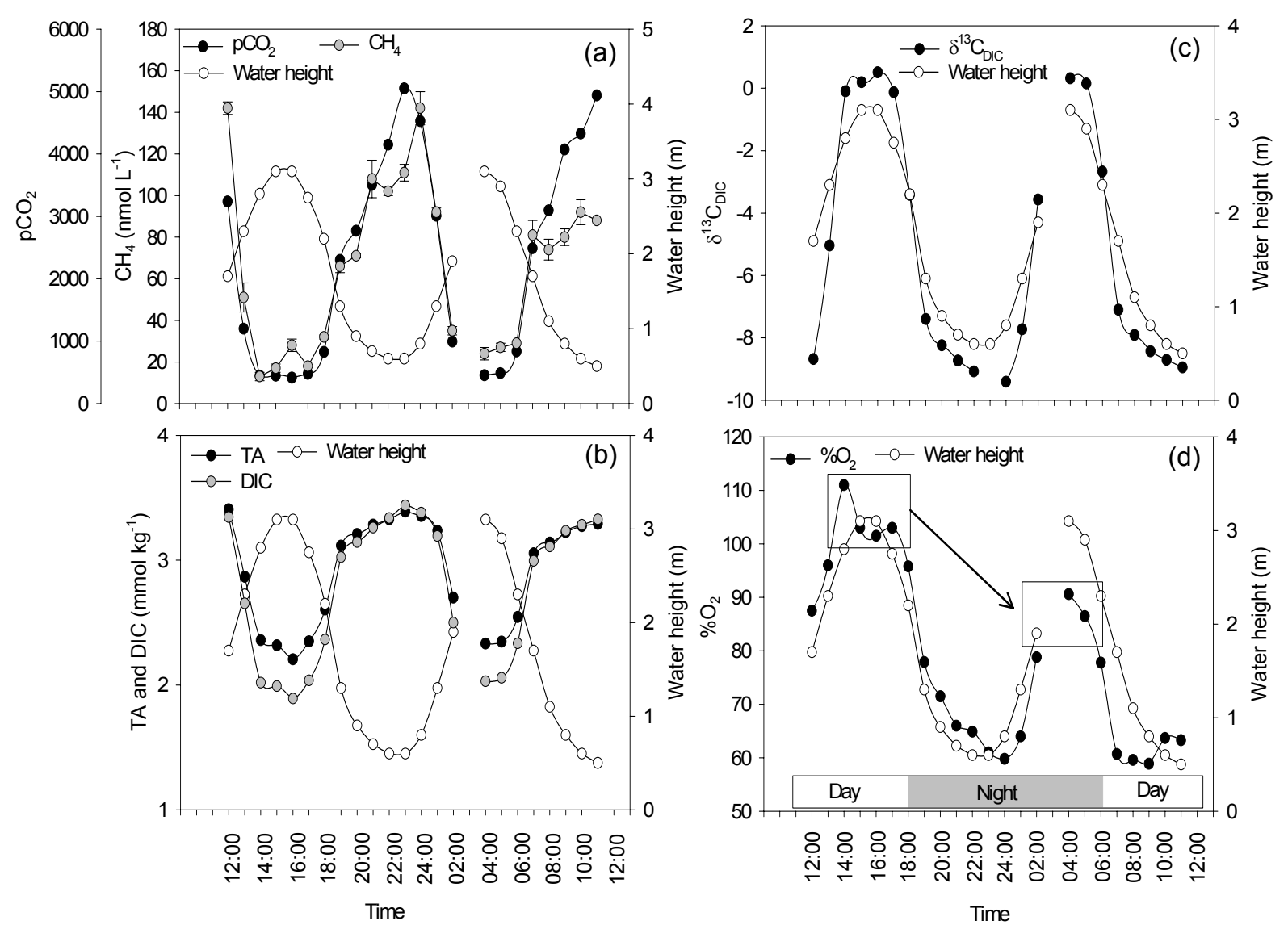

Fig. 5. Tidal variations of water height and (a) $\mathrm{CH}_{4}$ concentrations and $\mathrm{pCO}_{2}$, (b) total alkalinity and dissolved inorganic carbon concentrations, (c) $\delta^{13} \mathrm{C}$ signatures of dissolved inorganic carbon, and (d) dissolved oxygen saturation levels $\left(\% \mathrm{O}_{2}\right)$. Error bars on the $\mathrm{CH}_{4}$ concentrations are 1 s.d., based on triplicate measurements.

Table 1. Estimated porewater contributions to the creek water column at low tide, based on salinity, DOC, and $\% \mathrm{O}_{2}$ data on porewaters at different points along the creek and in creek waters during high tide and low tide, and (lower part) calculated porewater $\mathrm{CH}_{4}$, TA and DIC based on an average estimated porewater contribution of $31 \%$. Porewaters were assumed to be anoxic (i.e. $\% \mathrm{O}_{2}=0$ ), porewater salinity data and DOC concentrations: E. Kristensen, unpublished data.

\begin{tabular}{llccc}
\hline & Porewater & Ebb & Flood & \% porewater during ebb \\
\hline Salinity & 43.5 (average) & 37.5 & 34.8 & $\mathbf{3 1 \%}$ \\
& 49.1 (high values) & 37.5 & 34.8 & $\mathbf{1 9 \%}$ \\
DOC $\left(\mathrm{mg} \mathrm{C} \mathrm{L}^{-1}\right.$ ) & 37.9 (low values) & 37.5 & 34.8 & $\mathbf{8 7 \%}$ \\
& 7.40 (avg) & 2.57 & 0.79 & $\mathbf{2 7 \%}$ \\
$\% \mathrm{O}_{2}$ & 9.99 (high values) & 2.57 & 0.79 & $\mathbf{1 9 \%}$ \\
\hline
\end{tabular}

Estimated porewater concentrations using a fixed average porewater contribution of $31 \%$ :

\begin{tabular}{llccc}
\hline & Ebb & Flood & \% porewater & Estimated porewater concentration \\
\hline $\mathrm{CH}_{4}(\mathrm{nM})$ & 112 & 19 & $31 \%$ & $\mathbf{3 1 9}$ \\
$\mathrm{TA}\left(\mathrm{mmol} \mathrm{kg}^{-1}\right)$ & 3.36 & 1.97 & $31 \%$ & $\mathbf{6 . 4 6}$ \\
$\mathrm{DIC}\left(\mathrm{mmol} \mathrm{kg}^{-1}\right)$ & 3.34 & 2.29 & $31 \%$ & $\mathbf{5 . 6 6}$ \\
\hline
\end{tabular}


increase in POC/PN ratios (Fig. 3c), from values of $\sim 11-$ 12 at high and low tide to $>16$ during tidal stage changes, indicating that there was a sudden change in the origin of the particulate organic matter pool. The high POC/PN ratios and depleted $\delta^{13} \mathrm{C}$ signatures (see Fig. $4 \mathrm{~b}$ ) both indicate that mangrove detritus (with typical signatures between -26 and $-29 \%$ o, e.g. Bouillon et al. (2007a)) was the main source of organic carbon during these events. Other potential sources such as marine phytoplankton and seagrassderived organic matter are much more ${ }^{13} \mathrm{C}$-enriched, with expected signatures in the range of -22 to $-20 \%$ and -19 to $-11 \%$, respectively (see further). Moreover, the peaks in the \%POC/TSM during the current maxima (Fig. 3d) support the idea that the high levels of TSM and associated POC were caused by rapid resuspension or mobilization of organic-rich surface sediments from the mangrove floor. Indeed, the upper $10 \mathrm{~cm}$ of intertidal sediments collected near to the sampling station had TOC levels between 6.8 and $8.4 \%$, TOC/TN ratios between 17.2 and 20.0 , and $\delta^{13} \mathrm{C}$ values between -26.0 and $-25.6 \%$.

DOC concentrations closely followed the tidal changes in salinity, being highest at low tide (Fig. 4a), and were similar to the tidal variations observed by in a Brazilian mangrove system (Dittmar and Lara, 2001), a Thai mangrove (Kristensen and Suraswadi, 2002), and a basin mangrove forest in Florida (Twilley, 1985). These similarities suggest that this is a fairly universal pattern and that DOC variations are governed by similar mechanisms in different tidal mangrove creeks. A simple mass balance calculation indicates that pore-water derived DOC contributes about $30 \%$ to the DOC pool during the low tide slack (Table 1). Similarly, oxygen in creek waters during low tide is strongly undersaturated because of a significant input of oxygen depleted pore-water. Assuming that no oxygenation from the atmosphere occurred during the time interval between pore-water drainage and sampling, we derive a pore-water contribution of $34 \%$ during the low tide slack, consistent with the estimates based on DOC and salinity (Table 1). The variations in DOC during the tidal cycle are consistent with these estimated porewater contributions, when using the average DOC concentration of $7.4 \pm 2.6 \mathrm{mg} \mathrm{C} \mathrm{L}^{-1}(n=4)$ measured in sediment porewaters during the same field campaign. Mangroves and salt marshes have been considered as systems where a significant part of the ecosystem production is exported to the adjacent coastal zone (the "outwelling" hypothesis), and it has been suggested that most of the organic carbon is exported in the dissolved form (e.g., Lee, 1995; Dittmar et al., 2006). Consistent with this observation, we indeed found DOC to be the dominant organic $\mathrm{C}$ pool in the water column, comprising $\sim 70 \%$ of the total water column organic carbon pool during low tide.

$\delta^{13} \mathrm{C}$ signatures of both DOC and POC varied substantially in phase with the tidal cycle, and showed an overall range of 10.0 and $5.7 \%$, respectively (Fig. 4b). Concentrations and $\delta^{13} \mathrm{C}$ values were clearly linked for each of these

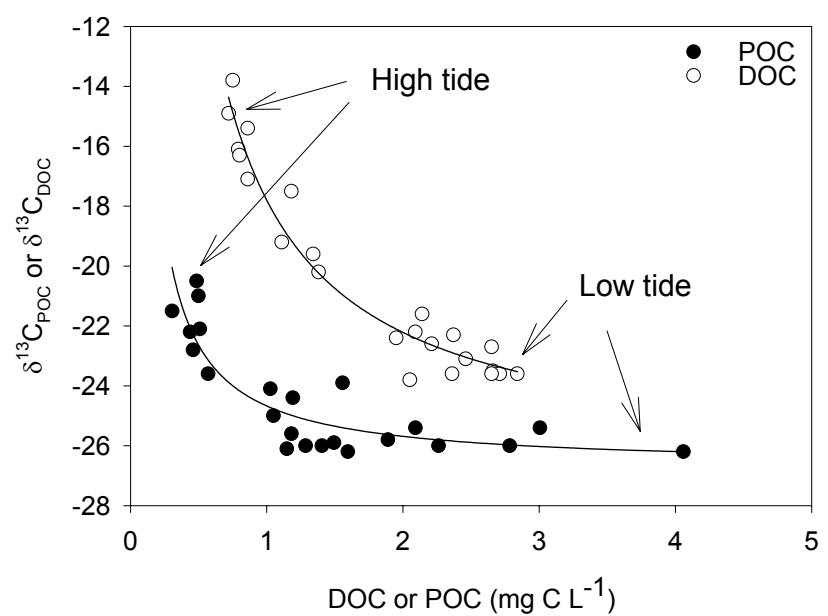

Fig. 6. Concentrations and $\delta^{13} \mathrm{C}$ signatures of particulate and dissolved organic carbon (dark and open symbols, respectively) during a diurnal cycle. Lines represent a fitted inverse first order polynomial, of the form $y=y_{0}+a / x$, with $y_{0}=-26.6 \pm 0.3$ for DOC and $-26.7 \pm 0.3$ (1 S.E.) for POC (see text for details).

pools, and their co-variation is consistent with mixing between two pools of organic carbon, i.e. marine and mangrove end-members (Fig. 6). These relationships can thus be used to estimate the $\delta^{13} \mathrm{C}$ signature of the DOC and POC "added" within the mangrove system, either directly from the inverse first order polynomial fit (i.e. $y=y_{0}+a / x$, see Fig. 6), or alternatively as the intercept of the linear regression between 1/DOC and $\delta^{13} \mathrm{C}_{\mathrm{DOC}}$ or $1 / \mathrm{POC}$ and $\delta^{13} \mathrm{C}_{\mathrm{POC}}$, respectively. The resulting mangrove end-member $\delta^{13} \mathrm{C}$ signatures are very similar: $-26.6 \pm 0.3$ and $-26.7 \pm 0.3 \%$ of DOC and POC, respectively. These values are within the expected range for mangrove-derived organic carbon (Bouillon et al., 2007a), confirming that mangrove primary production is the main source of organic matter derived from within the system boundaries. Moreover, this similarity indicates that despite potential differences in the biochemical composition of both pools, $\delta^{13} \mathrm{C}$ signatures of both POC and DOC derived from mangrove litter are similar. The latter is an important prerequisite to use these tracers in distinguishing the contribution of different sources to the POC and DOC pools and to unambiguously interpret small but significant differences in the $\delta^{13} \mathrm{C}$ composition of both pools as a difference in their source contributions (e.g. see Bouillon et al., 2007b).

However, marine end-member $\delta^{13} \mathrm{C}$ signatures for DOC and POC differed substantially, and demonstrate a distinct difference in their origin. Whereas the POC pool had signatures typical for marine phytoplankton ( -20 to $-22 \%$ o, e.g. Fontugne and Duplessy, 1981), the DOC pool has $\delta^{13} \mathrm{C}$ values around -16 to $-14 \%$, which is much more enriched than can be expected for marine phytoplankton. However, seagrasses which in our study site are found at the creek mouth and which cover large areas on the slope outside the system, 


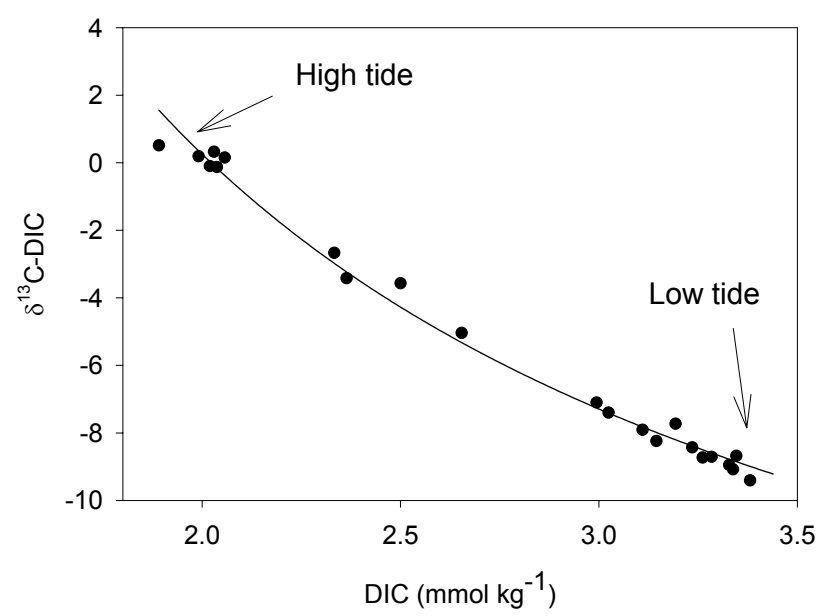

Fig. 7. Correlation between dissolved inorganic carbon concentrations and its stable isotope composition for samples collected during a diurnal cycle. Full line represents a fitted first order polynomial, of the form $y=y_{0}+a / x$, with $y_{0}=-22.4 \pm 0.4$.

are expected to have $\delta^{13} \mathrm{C}$ values within this range: although $\delta^{13} \mathrm{C}$ signatures for seagrasses were not determined in this particular system, other data from other sites along the east African coast range between -18.6 and $-10.7 \%$ o (Bouillon et al., 2004; Macia, 2004).

The observed difference in marine end-member $\delta^{13} \mathrm{C}$ signatures and in the timing of local maxima during the tidal cycle results in an offset in $\delta^{13} \mathrm{C}$ signatures between the dissolved and particulate pools. Thus, $\Delta \delta$ (defined as $\delta^{13} \mathrm{C}_{\mathrm{DOC}}-$ $\delta^{13} \mathrm{C}_{\mathrm{POC}}$ ) is minimal (0-2\%o) at low tide (when mangrovederived $\mathrm{C}$ is the main source in both pools), whereas large differences of up to $9 \%$ are observed during or shortly after high tide (Fig. 4c). Differences in the origin of particulate and dissolved organic carbon have previously been documented (Bouillon et al., 2006), but rarely as pronounced as shown here. More importantly, our study provides clear mechanisms explaining these strong variations (summarized in Sect. 4.4).

\subsection{Inorganic carbon and $\mathrm{CH}_{4}$ dynamics}

TA, DIC, and $\mathrm{pCO}_{2}$ showed tidal variations similar to those of DOC, i.e. their concentrations were inversely related to the tidal height (Figs. 5a, b), consistent with results from previous studies (e.g. Borges et al., 2003). As will be discussed below, the set of data related to the inorganic carbon pool demonstrate that (i) $\mathrm{pCO}_{2}$ supersaturation and the resulting fluxes of $\mathrm{CO}_{2}$ to the atmosphere are strongly variable, but significant and consistent with previous data from mangrove creeks, (ii) the tidal variations are consistent with the hypothesis that exchange through porewater seepage is important, and (iii) that material of non-mangrove origin contributes significantly to overall mineralization at the ecosystem level.
First, the observed range in $\mathrm{pCO}_{2}$ is extremely high (Fig. 5a), with low tide levels up to 10 -fold those at high tide and corresponding to an amplitude of $\sim 4500 \mathrm{ppm}$, similar to the one of $\sim 3500 \mathrm{ppm}$ reported by Borges et al. (2003) during a diurnal cycle in an Indian mangrove creek. The emission of $\mathrm{CO}_{2}$ to the atmosphere computed with the Raymond and Cole (2001) gas transfer velocity parameterisation (using wind speed data measured with a handheld anemometer) was on average $33 \mathrm{mmol} \mathrm{m}^{-2} \mathrm{~d}^{-1}$ (range $1-80 \mathrm{mmol} \mathrm{m}^{-2} \mathrm{~d}^{-1}$ ). Such high $\mathrm{CO}_{2}$ emission rates are consistent with literature estimates which range between $\sim 1$ and $\sim 200 \mathrm{mmol} \mathrm{m}^{-2}$ $\mathrm{d}^{-1}$ and show an average of $\sim 50 \mathrm{mmol} \mathrm{m}^{-2} \mathrm{~d}^{-1}$ for different sites (Borges et al., 2003).

Secondly, the inorganic carbon data presented here are again consistent with a strong influence of porewaters, which typically have high TA, high DIC and $\mathrm{pCO}_{2}$ (e.g. Bouillon et al., 2007b; simultaneously measured porewater DIC along the Ras Dege creek ranged up to $6 \mathrm{mM}$ ). As has been previously stressed for salt marshes and tidal freshwater marshes (Cai et al., 1999; Neubauer and Anderson, 2003), high $\mathrm{pCO}_{2}$ values in the water column do not necessarily imply a net heterotrophic water column, but can to some extent also be caused by mineralization in the intertidal areas and subsequent transport to the creek. Such an exchange mechanism thus acts as a $\mathrm{CO}_{2}$ "pump", transporting $\mathrm{CO}_{2}$ generated in intertidal sediments towards the water column where $\mathrm{CO}_{2}$ efflux towards the atmosphere takes place. The only evidence of significant net photosynthetic production in the water column at Ras Dege was the occurrence of distinctly higher oxygen saturation at high tide during the day than during the night (Fig. 5d).

Thirdly, the $\delta^{13} \mathrm{C}_{\mathrm{DIC}}$ (overall range between -9.4 and $+0.5 \%$ o) closely followed the tidal height (Fig. $5 \mathrm{c}$ ), and was inversely related to DIC concentrations (Fig. 7). The resulting inverse first order polynomial relationship between these variables is consistent with simple conservative mixing between two carbon sources. Assuming that the build-up of DIC is essentially due to mineralization, and neglecting the effect of $\mathrm{CO}_{2}$ outgassing on $\delta^{13} \mathrm{C}$ signatures of the DIC pool (which is acceptable as shown by the conservative fit in Fig. 7), the $\delta^{13} \mathrm{C}$ signature of the "added" DIC can be estimated to $-22.4 \pm 0.4 \%$ o from the relationship between DIC and $\delta^{13} \mathrm{C}_{\text {DIC. }} \mathrm{Ca}^{2+}$ data (not shown) do not indicate noticeable calcium carbonate dissolution, which further indicates that this approach is valid in our system. The estimated $\delta^{13} \mathrm{C}$ signal for the DIC produced is more ${ }^{13} \mathrm{C}$-enriched than expected if mangrove biomass $(\sim-27 \%$ o) or bulk sediment organic matter $(\sim-25 \%$ o) were the only organic matter sources for mineralization, but is close to the average signatures of the total (DOC and POC) water column organic carbon pool during one full tidal cycle $(-21.9 \pm 3.2 \%$ ). Thus, our data suggest that both marine organic matter (phytoplankton and seagrass-derived) and mangrove detritus contribute to mineralization within the mangrove forest boundary. This had been demonstrated previously based on isotope data of bacterial 


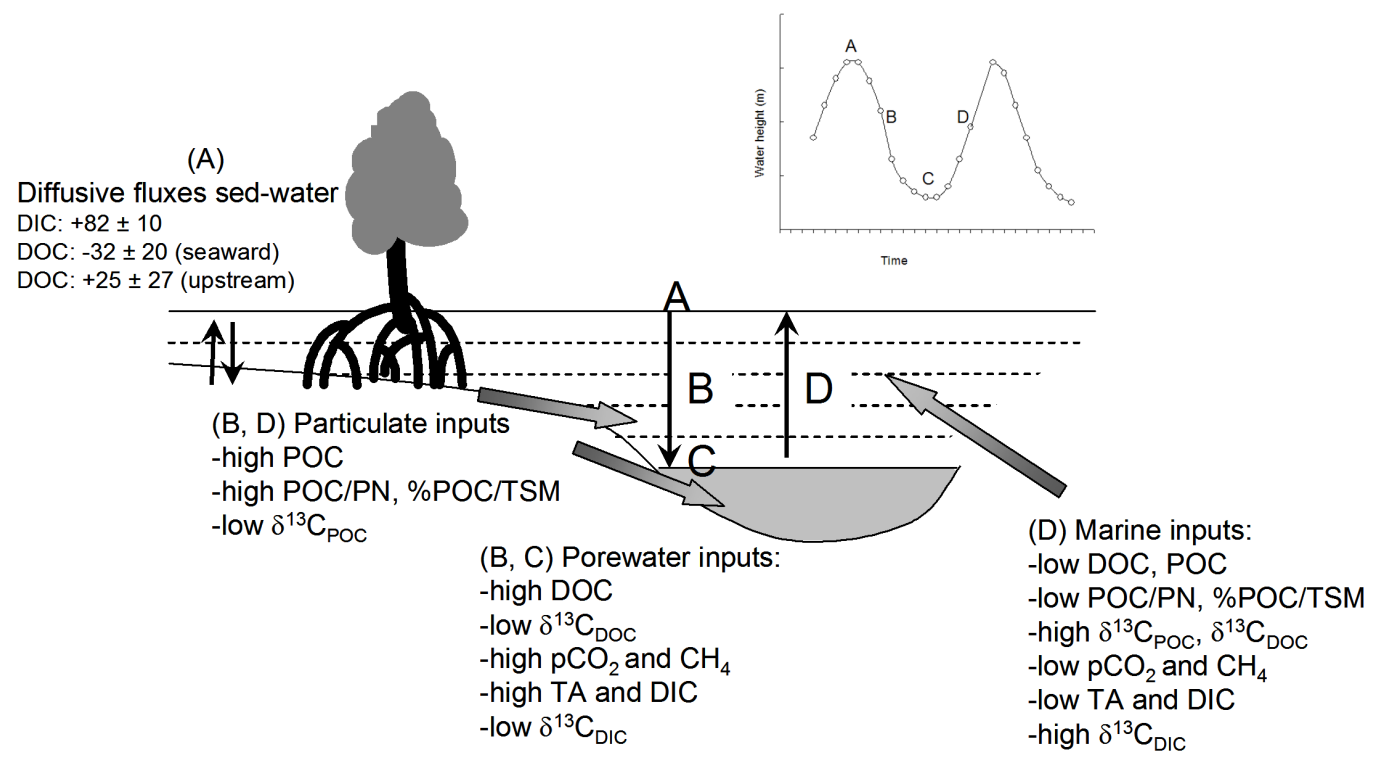

Fig. 8. Conceptual scheme of exchange processes for dissolved and particulate matter during a tidal cycle in the tidal creeks. Letters A, B, C, and D refer to high tide, ebb, low tide, and flood, respectively. Fluxes (E. Kristensen, unpublished) are presented in mmol $\mathrm{m}^{-2} \mathrm{~d}^{-1}$, positive fluxes are towards the water column, negative fluxes indicate net uptake by sediments.

markers (e.g. Bouillon et al., 2004), yet such data only referred to the upper layers of the sediments, where inputs of non-mangrove sources are likely to be most important (i.e. microphytobenthic production and deposition of suspended matter from the water column). Since mineralization in deeper sediment layers - where the organic matter is often to a larger extent mangrove-derived, e.g. Marchand et al. (2003) - can also reach high levels (Alongi et al., 2004), previous evidence from bacterial markers did not necessarily demonstrate the importance of allochtonous (i.e. nonmangrove) sources at the entire ecosystem level, whereas the approach used here does confirm that marine-derived organic matter contributes substantially to the integrated mineralization within the mangrove system boundaries.

The daily variations of $\mathrm{CH}_{4}$ in Ras Dege creek waters are similar to those recently reported for a mangrove creek on South Andaman Island (Barnes et al., 2006), except that the concentration range is lower in Ras Dege (13$142 \mathrm{nmol} \mathrm{L}^{-1}$ ) than observed by Barnes et al. (2006; range $\left.282-704 \mathrm{nmol} \mathrm{L}^{-1}\right)$. The tidal variations of $\mathrm{CH}_{4}$ closely follow the patterns observed in DIC and $\mathrm{pCO}_{2}$ (Figs. 5a, b). Since $\mathrm{CH}_{4}$ is produced under anoxic conditions, these co-variations provide further confirmation for the hypothesis that seepage of porewaters can be an important driver of solute exchange between the intertidal mangrove forest and tidal creeks. The average emission of $\mathrm{CH}_{4}$ to the atmosphere during the tidal cycle (computed with the Raymond and Cole (2001) gas transfer velocity parameterisation) was $29 \mu \mathrm{mol} \mathrm{m}^{-2} \mathrm{~d}^{-1}$, ranging between 0 and $185 \mu \mathrm{mol} \mathrm{m}^{-2} \mathrm{~d}^{-1}$, similar to values reported by Biswas et al. (2006) (2-135 $\left.\mu \mathrm{mol} \mathrm{m}^{-2} \mathrm{~d}^{-1}\right)$ but lower than the fluxes observed by Barnes et al. (2006) $\left(432-840 \mu \mathrm{mol} \mathrm{m}^{-2} \mathrm{~d}^{-1}\right.$ ). The computed diffusive $\mathrm{CH}_{4}$ fluxes under-estimate the overall $\mathrm{CH}_{4}$ emission due to a large but highly variable contribution of ebullition in the form of free gas (Barnes et al., 2006). Nevertheless, $\mathrm{CH}_{4}$ emission from mangrove systems are typically low when compared to freshwater wetland systems (Bartlett and Harriss, 1983), except in anthropogenically disturbed mangrove systems (Purvaja and Ramesh, 2001; Sotomayor et al., 1994; Giani et al., 1996; Alongi et al., 2005). Methanogenesis in mangrove sediments typically represents less than $2 \%$ of the overall $\mathrm{C}$ degradation, which is generally dominated by sulphate reduction and/or Fe reduction (Alongi, 1998). Moreover, the presence of sulphates can favour anaerobic oxidation of $\mathrm{CH}_{4}$ (Giani et al., 1996; Biswas et al., 2006), and the dominance of clay minerals and the frequent mobilization of surface sediments by tidal currents in mangroves systems can enhance aerobic methane oxidation both at the sediment surface and in the water column (Weaver and Dugan, 1972; Abril et al., 2007).

\subsection{Summary}

The observed daily variations in water column chemistry and isotopic signatures can be explained by different exchange processes for dissolved and particulate matter pools, as conceptualized in Fig. 8. There are two main sources of dissolved constituents, i.e. porewater seepage and marine inputs, and two main sources of particulate material, i.e. sediment detritus and marine particulate organic matter. The origin of both particulate and dissolved organic matter from 
within the system appears to be predominantly mangrovederived based on the $\delta^{13} \mathrm{C}$ signatures (Fig. 6). In contrast, while the marine source of DOC appears to be to a large extent derived from ${ }^{13} \mathrm{C}$-enriched seagrass material, marine POC seems predominantly of phytoplankton origin (Fig. 6). The carbon transport during high tide is dominated by diffusive solute (DOC, DIC) fluxes across the sediment-water interface (period a in Fig. 8), and settling of POC from the water column which to some extent is of marine phytoplankton origin (not shown in Fig. 8). During ebb (period b in Fig. 8), there is porewater solute seepage resulting in increasing concentrations of gradually more ${ }^{13} \mathrm{C}$-depleted DOC and DIC in the creek water, as well as higher $\mathrm{CH}_{4}$ and $\mathrm{pCO}_{2}$ values and lower $\mathrm{O}_{2}$ saturation levels. During tidal transitions, there is mobilization of particulate material likely through resuspension and sediment erosion, which causes a rapid increase in mangrove-derived TSM and POC as indicated by a decrease in $\delta^{13} \mathrm{C}_{\mathrm{POC}}$ and an increase in POC/PN ratios and $\% \mathrm{POC} / \mathrm{TSM}$ in the creek water. As the water current decreases towards low tide slack (period c in Fig. 8), the particulate material (TSM and POC) settles down again, but $\delta^{13} \mathrm{C}_{\mathrm{POC}}$ signatures remain low reflecting the dominance of mangrove-derived material. When the flood starts (period d in Fig. 8), the concentration of particulate material dominated by oceanic water signatures transiently increases with maximal tidal currents and then decreases until high tide slack.

In our study, biogeochemical processes in the intertidal zone, erosion of surface sediments, and exchange of porewater combined with the physical conditions related to the tidal cycle were thus important drivers of the concentrations and isotopic signatures of dissolved and particulate carbon in mangrove creek waters. Other processes responsible for enhanced exchange of particulate matter between intertidal zones and creek waters such as precipitation runoff (Twilley, 1985; Barnes et al., 2006) were not captured in the present dataset, given the fact that we only considered a single tidal cycle. Furthermore, it should be stressed that a number of other factors can be important in determining the net transport of particulate material in mangrove creeks, such as flocculation and trapping in maximum turbidity zones when present (see Wolanski, 1995), and that transport of macrolitter, which was not included in our analysis, could also be significant.

Acknowledgements. S. B. is funded by a postdoctoral mandate from the Research Foundation Flanders (FWO-Vlaanderen), and this research was partly accomplished during a postdoctoral stay at the NIOO-CEME. A. V. B. is a research associate with the FNRS, Belgium. This research was funded by the EC-STREP programme PUMSPEA (contract 510863), and the $\delta^{13} \mathrm{C}$-DOC analyses were made possible through a research grant from the FWO-Vlaanderen (contract 1.5.070.05) and the Research Council of the Vrije Universititeit Brussel. Thanks are due to Y. P. Mhonda for his cheerful company during the 24-h sampling, to M. Korntheuer for his excellent technical help in setting up and maintaining the
DOC-IRMS, and to G. Neukermans for providing details on the mangrove vegetation and extent in the study area. D. P. Gillikin, T. Jennerjahn, 2 anonymous reviewers, and A. Boetius (handling editor) provided excellent and constructive comments to this manuscript. This is publication 4078 of the Netherlands Institute of Ecology (NIOO-KNAW).

Edited by: A. Boetius

\section{References}

Abril, G. and Iversen, N.: Methane dynamics in a shallow, nontidal, estuary (Randers Fjord, Denmark), Mar. Ecol. Prog. Ser., 230, 171-181, 2002.

Abril, G., Commarieu, M.-V., and Guérin, F.: Enhanced methane oxidation in an estuarine turbidity maximum, Limnol. Oceanogr., 52, 470-475, 2007.

Alongi, D. M.: Coastal ecosystem processes, CRC Press, 419 p., 1998.

Alongi, D. M.: Present state and future of the world's mangrove forests, Environ. Conserv., 29, 331-349, 2005.

Alongi, D. M., Sasekumar, A., Chong, V. C., Pfitzner, J., Trott, L. A., Tirendi, F., Dixon, P., and Brunskill, G. J.: Sediment accumulation and organic material flux in a managed mangrove ecosystem: estimates of land-ocean-atmosphere exchange in peninsular Malaysia, Mar. Geol., 208, 383-402, 2004.

Alongi, D. M., Clough, B. F., and Robertson, A. I.: Nutrient-use efficiency in arid-zone forests of the mangroves Rhizophora stylosa and Avicennia marina, Aquat. Bot., 82, 121-131, 2005.

Alongi, D. M., Pfitzner, J., Trott, L. A., Dixon, P., and Klumpp, D. W.: Rapid sediment accumulation and microbial mineralization in forests of the mangrove Kandelia candel in the Jiulongjiang estuary, China, Estuar. Coast. Shelf Sci., 63, 605-618, 2005.

Bartlett, K. B. and Harriss, R. C.: Review and assessment of methane emissions from wetlands, Chemosphere, 26, 261-320, 1993.

Barnes, J., Ramesh, R., Purvaja, R., Nirmal Rajkumar, A., Senthil Kumar, B., Krithika, K., Ravichandran, K., Uher, G., and UpstillGoddard, R.: Tidal dynamics and rainfall control $\mathrm{N}_{2} \mathrm{O}$ and $\mathrm{CH}_{4}$ emmissions from a pristine mangrove creek, Geophys. Res. Lett., 33, L15405, doi:10.1029/2006GL026829, 2006.

Billerbeck, M., Werner, U., Bosselmann, K., Walpersdorf, E., and Huettel, M.: Nutrient release from an exposed intertidal sand flat, Mar. Ecol. Prog. Ser., 316, 35-51, 2006 a.

Billerbeck, M., Werner, U., Polerecky, L., Walpersdorf, E., deBeer, D., and Huettel, M.: Surficial and deep pore water circulation governs spatial and temportal scales of nutrient recycling in intertidal sand flat sediments, Mar. Ecol. Prog. Ser., 326, 61-76, $2006 b$.

Biswas, H., Mukhopadhyay, S. K., Sen, S., and Jana, T. K.: Spatial and temporal patterns of methane dynamics in the tropical mangrove dominated estuary, NE coast of Bay of Bengal, India, J. Mar. Syst., doi:10.1016/j.jmarsys.2006.11.001, 2006.

Borges, A. V.: Do we have enough pieces of the jigsaw to integrate $\mathrm{CO}_{2}$ fluxes in the Coastal Ocean?, Estuaries, 28, 3-27, 2005.

Borges, A. V., Djenidi, S., Lacroix, G., Théate, J., Delille, B., and Frankignoulle, M.: Atmospheric $\mathrm{CO}_{2}$ flux from mangrove surrounding waters, Geophys. Res. Lett., 30, 1558, doi:10.1029/ 2003GL017143, 2003. 
Boto, K. G. and Bunt, J. S.: Tidal export of particulate organic matter from a northern Australian mangrove system, Estuar. Coast. Shelf Sci., 13, 247-255, 1981.

Bouillon, S., Frankignoulle, M., Dehairs, F., Velimirov, B., Eiler, A., Etcheber, H., Abril, G., and Borges, A. V.: Inorganic and organic carbon biogeochemistry in the Gautami Godavari estuary (Andhra Pradesh, India) during pre-monsoon: the local impact of extensive mangrove forests, Global Biogeochem. Cy., 17, 1114, doi:10.1029/2002GB002026, 2003.

Bouillon, S., Moens, T., and Dehairs, F.: Carbon sources sustaining benthic mineralization in mangrove and adjacent seagrass sediments (Gazi bay, Kenya), Biogeosciences, 1, 71-78, 2004, http://www.biogeosciences.net/1/71/2004/.

Bouillon, S., Korntheuer, M., Baeyens, W., and Dehairs, F.: A new automated setup for stable isotope analysis of dissolved organic carbon, Limnol. Oceanogr.: Methods, 4, 216-226, 2006.

Bouillon, S., Connolly, R., and Lee, S. Y.: Carbon exchange and cycling in mangrove ecosystems: a synthesis of recent insights based on stable isotope studies, J. Sea Res., doi:10.1016/j.seares.2007.05.001, in press, 2007a.

Bouillon, S., Dehairs, F., Schiettecatte, L.-S., and Borges, A. V.: Biogeochemistry of the Tana estuary and delta (northern Kenya), Limnol. Oceanogr., 52, 46-59, 2007b.

Cai, W.-J., Pomeroy, L. R., Moran, M. A., and Wang, Y.: Oxygen and carbon dioxide mass balance for the estuarine-intertidal marsh complex of five rivers in the southeastern U.S., Limnol. Oceanogr., 44, 639-649, 1999.

Cai, W.-J., Wiebe, W. J., Wang, Y., and Sheldon, J. E.: Intertidal marsh as a source of dissolved inorganic carbon and a sink of nitrate in the satilla river-estuarine complex in the southeastern U.S. Limnol. Oceanogr., 45, 1743-1752, 2000.

Davis, S. E., Childers, D. L., Day, J. W., Rudnick, D. T., and Sklar, F. H.: Wetland-water column exchanges of carbon, nitrogen, and phosphorus in a southern Everglades dwarf mangrove, Estuaries, 24, 610-622, 2001.

Dittmar, T. and Lara, R. J.: Driving forces behind nutrient and organic matter dynamics in a mangrove tidal creek in North Brazil, Estuar. Coast. Shelf Sci., 52, 249-259, 2001.

Dittmar, T., Hertkorn, N., Kattner, G., and Lara, R. J.: Mangroves, a major source of dissolved organic carbon to the oceans, Global Biogeochem. Cy., 20, GB1012, doi:10.1029/2005GB002570, 2006.

Duarte, C. M., Middelburg, J. J., and Caraco, N.: Major role of marine vegetation on the oceanic carbon cycle, Biogeosciences, 2, 1-8, 2005, http://www.biogeosciences.net/2/1/2005/.

Flindt, M. R., Neto, J., Amos, C. L., Pardal, M. A., Bergamasco, A., Pedersen, C. B., and Andersen, F. Ø.: Plant bound nutrient transport. Mass transport in estuaries and lagoons, in: Estuarine nutrient cycling: the influence of primary producers. The fate of nutrient biomass, edited by: Nielsen, S. L., Banta, G. T., and Pedersen, M. F., Series: Aquatic Ecology, Vol. 2, 2004.

Flindt, M. R., Pedersen, C. B., Amos, C. L., Levy, A., Bergamasco, A., and Friend, P. L.: Transport, sloughing and settling rates of estuarine macrophytes: mechanisms and ecological implications Cont. Shelf Res., 27, 1096-1103, 2007.

Fontugne, M. R. and Duplessy, J. C.: Organic carbon isotopic fractionation by marine plankton in the temperature range -1 to $31^{\circ} \mathrm{C}$, Oceanol. Acta, 4, 85-90, 1981.
Frankignoulle, M. and Borges, A. V.: Direct and indirect $\mathrm{pCO}_{2}$ measurements in a wide range of $\mathrm{pCO}_{2}$ and salinity values (the Scheldt estuary), Aquat. Geochem., 7, 267-273, 2001.

Gattuso, J.-P., Frankignoulle, M., and Wollast, R.: Carbon and carbonate metabolism in coastal aquatic ecosystems, Ann. Rev. Ecol. Syst., 29, 405-433, 1998.

Giani, L., Bashan, Y., Holguin, G., and Strangmann, A.: Characteristics and methanogenesis of the Balandra lagoon mangrove soils, Baja California Sur, Mexico, Geoderma, 72, 149-160, 1996.

Gribsholt, B., Boschker, H. T. S., Struyf, E., Andersson, M., Tramper, A., De Brabandere, L., Van Damme, S., Brion, N., Meire, P., Dehairs, F., Middelburg, J. J., and Heip, C.: Nitrogen processing in a tidal freshwater marsh: a whole ecosystem ${ }^{15} \mathrm{~N}$ labeling study, Limnol. Oceanogr., 50, 1945-1959, 2005.

Hall, P. O. and Aller, R. C.: Rapid, small-volume, flow injection analysis for $\mathrm{ECO}_{2}$ and $\mathrm{NH}_{4}^{+}$in marine and freshwaters, Limnol. Oceanogr., 37, 1113-1119, 1992.

Jennerjahn, T. C. and Ittekkot, V.: Relevance of mangroves for the production and deposition of organic matter along tropical continental margins, Naturwissenschaften, 89, 23-30, 2002.

Kitheka, J. U.: Water circulation and coastal trapping of brackish water in a tropical mangrove-dominated bay in Kenya, Limnol Oceanogr., 41, 169-176, 1996.

Kitheka, J. U., Ongwenyi, G. S., and Mavuti, K. M.: Dynamics of suspended sediment exchange and transport in a degraded mangrove creek in Kenya, Ambio, 31, 580-587, 2002.

Kristensen, E., Andersen, F. O., Holmboe, N., Holmer, M., and Thongtham, N.: Carbon and nitrogen mineralization in sediments of the Bangrong mangrove area, Phuket, Thailand, Aquat. Microb. Ecol., 22, 199-213, 2000.

Kristensen, E. and Suraswadi, P.: Carbon, nitrogen and phosphorus dynamics in creek water of a southeast Asian mangrove forest, Hydrobiologia, 474, 197-211, 2002.

Kristensen, E. and Alongi, D. M.: Control by fiddler crabs (Uca vocans) and plant roots (Avicennia marina) on carbon, iron and sulfur biogeochemistry in mangrove sediment, Limnol. Oceanogr., 51, 1557-1571, 2006.

Kruitwagen, G., Hecht, T., Pratap, H. B., and Wendelaar Bonga, S. E.: Changes in morphology and growth of the mudskipper ( $P e-$ riophthalmus argentilineatus) associated with coastal pollution, Mar. Biol., 149, 201-211, 2005.

Lee, S. Y.: Mangrove outwelling: a review, Hydrobiologia, 295, 203-212, 1995.

Lee, S. Y.: Potential trophic importance of the faecal material of the mangrove sesarmine crab Sesarma messa, Mar. Ecol. Prog. Ser. 159, 275-284, 1997.

Lee, S. Y.: Ecological role of grapsid crabs in mangrove ecosystems: a review, Mar. Freshwater Res., 49, 335-343, 1998.

Ludwig, W., Probst, J. L., and Kempe, S.: Predicting the oceanic input of organic carbon by continental erosion, Global Biogeochem. Cy., 10, 23-41, 1996.

Macia, A.: Primary carbon sources for juvenile penaeid shrimps in a mangrove-fringed Bay of Inhaca Island, Mozambique: a dual carbon and nitrogen isotope analysis, W. Ind. Ocean J. Mar. Sci., 3, 151-161, 1995

Marchand, C., Lallier-Vergès, E., and Baltzer, F.: The composition of sedimentary organic matter in relation to the dynamic features of a mangrove-fringed coast in French Guiana, Estuar. 
Coast. Shelf Sci., 56, 119-130, 2003.

Marchand, C., Albéric, P., Lallier-Vergès, E., and Baltzer, F.: Distribution and characteristics of dissolved organic matter in mangrove sediment pore waters along the coastline of French Guiana, Biogeochem., 81, 59-75, 2006.

Mazda, Y. and Ikeda, Y.: Behavior of the groundwater in a riverinetype mangrove forest, Wetl. Ecol. Manag., 14, 477-488, 2006.

McClain, M. E, Boyer, E. W., Dent, L., Gergel, S. E., Grimm, N. B., Groffman, P. M., Hart, S. C., Harvey, J. W., Johnston, C. A., Mayorga, E., McDowell, W. H., and Pinay, G.: Biogeochemical hot spots and hot moments at the interface of terrestrial and aquatic ecosystems, Ecosystems, 6, 301-312, 2003.

Middelburg, J. J., Duarte, C. M., and Gattuso, J.-P.: Respiration in coastal benthic communities, in: Respiration in aquatic ecosystems, edited by: del Giorgio, P. A. and Williams, P. J. le B., Oxford Univ. Press, 2005.

Miyajima, T., Yamada, Y., Hanba, Y. T., Yoshii, K., Koitabashi, T., and Wada, E.: Determining the stable-isotope ratio of total dissolved inorganic carbon in lake water by GC/C/IRMS, Limnol. Oceanogr., 40, 994-1000, 1995.

Neubauer, S. C. and Anderson, I. C.: Transport of dissolved inorganic carbon from a tidal freshwater marsh to the York River estuary, Limnol. Oceanogr., 48, 299-307, 2003.

Ovalle, A. R. C, Rezende, C. E., Lacerda, L. D., and Silva, C. A. R.: Factors affecting the hydrochemistry of a mangrove tidal creek, Sepetiba Bay, Brazil, Estuar. Coast. Shelf Sci., 31, 639650, 1990

Purvaja, R. and Ramesh, R.: Natural and anthropogenic methane emission from wetlands of south India, Environ. Manag., 27, 547-557, 2001.

Purvaja, R., Ramesh, R., and Frenzel, P.: Plant-mediated methane emission from an Indian mangrove, Global Change Biol., 10, 1825-1834, 2004.
Raymond, P. A. and Cole, J. J.: Gas exchange in rivers and estuaries: choosing a gas transfer velocity, Estuaries, 24, 312-317, 2001.

Ridd, P. V.: Flow through animal burrows in mangrove creeks, Estuar. Coast. Shelf Sci., 43, 617-625, 1996.

Sotomayor, D., Corredor, J. E., and Morell, J. M.: Methane flux from mangrove sediments along the Southwestern Coast of Puerto Rico, Estuaries, 17, 140-147, 1994.

Susilo, A. and Ridd, P. V.: The bulk hydraulic conductivity of mangrove soil perforated with animal burrows, Wetl. Ecol. Manag., 13, 123-133, 2005.

Susilo, A., Ridd, P. V., and Thomas, S.: Comparison between tidally driven groundwater flow and flushing of animal burrows in tropical mangrove swamps, Wetl. Ecol. Manag., 13, 377-388, 2005.

Twilley, R. R.: The exchange of organic carbon in basin mangrove forests in a southwest Florida estuary. Estuar. Coast. Shelf Sci., 20, 543-557, 1985.

Victor, S., Golbuu, Y., Wolanski, E., and Richmond, R. H.: Fine sediment trapping in two mangrove-fringed estuaries exposed to contrasting land-use intensity, Palau, Micronesia, Wetl. Ecol. Manag., 12, 277-283, 2004.

Weaver, T. L. and Dugan, P. R.: Enhancement of bacterial methane oxidation by clay minerals, Nature, 237, 518, 1972.

Wolanski, E.: An evaporation-driven salinity maximum in Australian tropical estuaries, Estuar. Coast. Shelf Sci., 22, 415-424, 1986.

Wolanski, E.: Transport of sediment in mangrove swamps, Hydrobiologia, 295, 31-42, 1995.

Yamamoto, S., Alcauskas, J. B., and Crozier, T. E.: Solubility of methane in distilled water and seawater, J. Chem. Eng. Data., 21, 78-80, 1976 . 